九病虫研会報 $64 ： 80-88 （ 2018 ）$

Kyushu Pl. Prot. Res. 64 : 80-88 (2018)

\title{
熊本市近郊においてツルマメを摂食するチョウ目，コウチュウ目， バッ夕目昆虫の主要種およびそれらの発生消長
}

\author{
水谷 信夫 $^{1) \dagger} \cdot$ 大木 信彦 $^{1)} \cdot$ 安田 耕司 $^{21}$ \\ (1) 農研機構九州沖縄農業研究センター・ \\ 2) 農研機構農業環境変動研究センター)
}

\begin{abstract}
Lepidopteran, coleopteran and orthopteran insects feeding on wild soybean, Glycine soja Sieb. et Zucc., and their seasonal occurrences in Kumamoto. Nobuo Mizutani $^{1 \dagger \dagger}$, Nobuhiko Oki ${ }^{1)}$, Koji Yasuda ${ }^{2)}\left({ }^{1)}\right.$ NARO Kyushu Okinawa Agricultural Research Center, Suya 2421, Koshi, Kumamoto 861-1192, Japan. ${ }^{2)}$ NARO Institute for Agro-Environmental Sciences, Kannondai 3-1-3, Tsukuba, Ibaraki 305-8604, Japan)
\end{abstract}

\begin{abstract}
Fauna of lepidopteran, coleopteran and orthopteran insects feeding on wild soybean, Glycine soja Sieb. et Zucc., and abundance of respective species in vegetations including wild soybean were investigated in Kumamoto City and its environs (Kumamoto, Kashima, Ozu, Koshi and Shisui) from 2011 to 2015. Lepidopteran insects, Paragabara ochreipennis, Omiodes miserus, O. indicatus, Matsumuraeses falca, and Pleuroptya ruralis were found in abundance at many surveyed vegetations. Coleopteran insects, Medythia nigrobilineata and Popillia japonica, as well as orthopteran insects Patanga japonica and Oecamthus euryelytra were found in abundance at only some surveyed vegetations. Many coleopteran and orthopteran insects were found in Kashima, whereas few in Shisui. It seems that the difference in abundance of each species among the surveyed vegetations could be caused by the presence and amount of host plants in the field habitat including the surrounding environment.
\end{abstract}

Keywords : Glycine soja, folivorous insect, Lepidoptera, Coleoptera, Orthoptera

\section{緒言}

ツルマメ Glycine soja Sieb. et Zucc.は，日本，朝 鮮半島，中国，極東地域に隣接するロシアなどに分布 するマメ科の一年生植物で，ダイズ Glycine max (L.) Merr.の祖先野生種と考えられている (Hymowitz, 1970)。ダイズとッルマメは相互交雑が可能である （Karasawa, 1936；Oka, 1983）ことから，遺伝子組換 えダイズとの交雑による組換え遺伝子の混入がッルマ メを含む生態系に何らかの影響を及ぼすことが懸念さ れる。このうち，害虫抵抗性を持つ Bt ダイズについ ては, Bt 遺伝子のツルマメへの混入が Bt 毒素に感受 性のあるチョウ目昆虫等に影響を及ぼす可能性が考え られる。Bt 遺伝子のツルマメへの混入による生態的

nobuo@affrc.go.jp
影響を評価するためにはツルマメを寄主植物とする昆 虫相の解明が必要であるが，これまで断片的な情報し かなかった。このため, 国内数カ所のツルマメ自生地 で調査が行われ，そのうち，チョウ目昆虫についての 概要（安田ら，2012）と中国・四国地方における昆虫 相（菊地，2013）について報告された。

本報では，ツルマメを寄主植物とする昆虫種を明ら かにするため実施された上記の調査の一環として， 2011 2015年に熊本市近郊のッルマメ自生地において 行った調査のうち, チョウ目, コウチュウ目, バッ夕 目とその主要種の発生量に関する結果について報告す る。なお，2011年のチョウ目の調査結果については, 一部が安田ら（2012）と重複するが，発生量や発生消 長は未掲載であるため再録した。

本文に先立ち，調査標本の同定にご協力いただいた 松沢春雄氏, 佐藤力夫氏, 吉安裕氏, 栗原隆氏, 野村 
周平氏, 神保宇嗣氏, 吉松慎一氏, 中谷至伸氏に厚く お礼申し上げる。

なお, 本調査は, 農林水産省委託プロジェクト「新 農業展開ゲノムプロジェクト：次世代遺伝子組換え生 物の生物多様性影響評価手法の確立及び遺伝子組換え 作物の区分管理技術等の開発」の課題として実施した。

\section{材料および方法}

調查は Table 1に示した熊本市近郊のツルマメ自生 地 5 地点で2011〜2015年に行った。このうち, 熊本市 画図町, 嘉島町上仲間, 泗水町田島はそれぞれ加勢川, 緑川, 合志川の河川敷の, 大津町瀬田は用水路脇の, 合志市野々島は耕作放棄畑のツルマメが優占する植物 群落（以下，ツルマメ群落と表記する）で，いずれの 調查地もイネ科, マメ科等の植物が混生していた。調 查期間は Table 1に示したとおりで, ツルマメ群落を 確認後, 原則としてッルマメ種子が飛散するまでとし た。なお，2011年の大津町瀬田は除草作業によって, 2012年の嘉島町上仲間と2013年の泗水町田島は河川敷 内㧍よび堤防の工事によってッルマメ群落が消失した ため中途で調査を中止した。

調查は, 各調查場所のツルマメ群落から任意の場所 を選択し, 植物体上に生息する昆虫の種掞よび個体数 を見取り法によって記録した。調査間隔は 5 ～14日, 調查者は 1 名で調査時間は原則 60 分間とし, ツルマメ 群落の大きさおよび繁茂状況に合わせて調査時間を調 整した（15〜70分）上で, 選択したツルマメ群落の全 体をまんべんなく調査した。調査した昆虫種は, Bt 毒素の影響を受けやすいと考えられるチョウ目昆虫の 幼虫のほか, コウチュウ目の成虫, バッ夕目の成虫抒 よび幼虫で, 下記の方法で摂食が確認された種のみを 対象とした。チョウ目の幼虫については, 発見した幼 虫を採集し, 室内で羽化させた成虫を用いて種を同定 した。また，コウチュウ目やバッ夕目の成虫または幼 虫についても一部を採集し, 種の同定やッルマメの摂 食の有無を室内で確認した。これらの採集した個体は, $25^{\circ} \mathrm{C}, 16 \mathrm{~L} 8 \mathrm{D}$ の条件下で, 野外から採集し水挿しし たツルマメを慨として与え室内で飼育した。なお, 2011年と2012年はチョウ目昆虫のみを調查対象とし, コウチュウ目とバッタ目の調査は行わなかった。

調査対象の昆虫のうち, コウチュウ目のヒメコガネ Anomala rufocuprea Motschulsky, ドウガネブイブ イ A. cuprea Hope, コガネムシ Mimela splendens (Gyllenhal)については調查開始時に種を区別しな かったこと,また, マルキバネサルハムシ Pagria
Table 1. Survey sites and periods of insects feeding on wild soybean, Glycine soja, in Kumamoto

\begin{tabular}{lcccc}
\hline \multicolumn{1}{c}{ Location } & Year & Longitude (N) & Latitude (E) & survey period \\
\hline Tajima, Shisui & 2011 & $32^{\circ} 55^{\prime} 93.2$ & $130^{\circ} 45^{\prime} 06.4$ & Aug 18 - Oct 7 \\
& 2012 & $32^{\circ} 55^{\prime} 93.2$ & $130^{\circ} 45^{\prime} 06.4$ & Apr 5 - Nov 20 \\
& 2013 & $32^{\circ} 55^{\prime} 93.2$ & $130^{\circ} 45^{\prime} 06.4$ & May 24 - Sep 17 \\
& 2014 & $32^{\circ} 55^{\prime} 93.2$ & $130^{\circ} 45^{\prime} 06.4$ & May 30 - Nov 4 \\
& 2015 & $32^{\circ} 55^{\prime} 93.2$ & $130^{\circ} 45^{\prime} 06.4$ & Apr 28 - Nov 2 \\
Kaminakama, Kashima & 2011 & $32^{\circ} 44^{\prime} 23.2$ & $130^{\circ} 44^{\prime} 37.3$ & Jul 8 - Oct 27 \\
& 2012 & $32^{\circ} 44^{\prime} 23.2$ & $130^{\circ} 44^{\prime} 37.3$ & Apr 5 - Jun 26 \\
& 2013 & $32^{\circ} 44^{\prime} 16.6$ & $130^{\circ} 44^{\prime} 35.8$ & May 24 - Dec 13 \\
& 2014 & $32^{\circ} 44^{\prime} 16.6$ & $130^{\circ} 44^{\prime} 35.8$ & Apr 16 - Nov 19 \\
Nonoshima, Koshi & 2015 & $32^{\circ} 44^{\prime} 16.6$ & $130^{\circ} 44^{\prime} 35.8$ & Apr 28 - Nov 2 \\
& 2011 & $32^{\circ} 53^{\prime} 59.8$ & $130^{\circ} 43^{\prime} 67.8$ & Aug 25 - Oct 27 \\
Ezu, Kumamoto & 2012 & $32^{\circ} 53^{\prime} 59.8$ & $130^{\circ} 43^{\prime} 67.8$ & Apr 5 - Nov 20 \\
Seta, Ozu & 2011 & $32^{\circ} 45^{\prime} 10.8$ & $130^{\circ} 44^{\prime} 07.2$ & Jun 30 - Nov 1 \\
\hline
\end{tabular}

ussuriensis Moseyko et Medvedev, ツヤキバネサル ハムシ P. flavopustulata (Baly), アオバネサルハム シ Basilepta fulvipes (Motschulsky) については, 調 查時の目視による種の識別が困難であったため, それ ぞれコガネムシ類, サルハムシ類として扱った。また, チョウ目のダイズギンモンハモグリ Microthauma glycinella Kuroko は, 食害葉内における幼虫の生息 の有無を確認しなかったため個体数の調查からは除外 した。

\section{結果}

\section{1) 䎼食が確認された種および確認個体数}

今回の調查で, チョウ目で 8 科 29 種, バッタ目で 4 科 4 種, コウチュウ目で 4 科 11 種の摂食を確認した (Table 2)。このうち, チョウ目についてはダイズギ ンモンハモグリ, モンキチョウ Colias erate poliographa Motschulsky およびウンモンクチバ Mocis annetta (Butler) を除いた種の, バッタ目, コウチュウ目については複数の調査日で生息が確認さ れた種またはグループの確認個体数を Table 3〜5に 示した。なお，以下の記載においては，チョウ目昆虫 は幼虫を, バッ夕目は成虫と幼虫を, コウチュウ目に ついては成虫のことを示す。

チョウ目では, チャバネキボシアッバ Paragabara ochreipennis Sugi, ヒメクロミスジノメイガ Omiodes miserus (Butler), マエウスキノメイガ O. indicatus (Fabricius), ダイズサヤムシガ Matsumuraeses falcana (Walsingham), ウコンノメ イガ Pleuroptya ruralis（Scopoli）の発生がほぼ全て の調查地で認められ, 確認個体数も多かった（Table 3)。このうち, チャバネキボシアツバ以外の 4 種は, 確認個体数の年次変動も大きかった。ウスイロキンノ 
Table 2. List of lepidopteran, coleopteran and orthopteran insects feeding on wild soybean, G. soja, in Kumamoto (2011-2015)

\begin{tabular}{|c|c|c|c|}
\hline $\begin{array}{l}\text { Family } \\
\text { Species }\end{array}$ & Japanese name & $\begin{array}{l}\text { Family } \\
\text { Species }\end{array}$ & Japanese name \\
\hline LEPIDOPTERA & & COLEOPTERA & \\
\hline Lyonetiidae & & Scarabaeidae & \\
\hline \multirow{2}{*}{ Microthauma glycinella Kuroko } & ダイズギンモンハモグリ & Popillia japonica Newman & マメコガネ \\
\hline & & Anomala rufocuprea Motschulsky & ヒメコガネ \\
\hline Gelechiidae & & Anomala cuprea Hope & ドウガネブイブイ \\
\hline \multirow[t]{2}{*}{ Dichomeris acuminata (Staudinger) } & コフサキバガ & Mimela splendens (Gyllenhal) & コガネムシ \\
\hline & & Meloidae & \\
\hline Tortricidea & & Epicauta gorhami Marseul & マメハンミョウ \\
\hline Homona magnanima Diakonoff & チャハマキ & & \\
\hline Adoxophyes honmai Yasuda & チャノコカクモンハマキ & Chrysomelidae & \\
\hline Dentisociaria armata okui Yasuda & 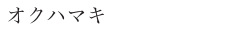 & Pagria ussuriensis Moseyko et Medvedev & マルキバネサルハムシ \\
\hline \multirow[t]{2}{*}{ Matsumuraeses falcana (Walsingham) } & ダイズサヤムシガ & Pagria flavopustulata (Baly) & ツヤキバネサルハムシ \\
\hline & & Basilepta fulvipes (Motschulsky) & アオバネサルハムシ \\
\hline Crambidae & & Medythia nigrobilineata (Motschulsky) & フタスジヒメハムシ \\
\hline Omiodes miserus (Butler) & ヒメクロミスジノメイガ & & \\
\hline Omiodes indicatus (Fabricius) & マエウスキノメイガ & Buprestidae & \\
\hline Pleuroptya punctimarginalis (Hampson) & ウスイロキンノメイガ & Trachys auricollis Saunders & クズノチビタマムシ \\
\hline \multirow[t]{2}{*}{ Pleuroptya ruralis (Scopoli) } & ウコンノメイガ & Trachys reitteri Obenberger & マメチビタマムシ \\
\hline & & ORTHOPTERA & \\
\hline Pyralidae & & Pyrgomorphidae & \\
\hline Salma elegans (Butler) & ナカアオフトメイガ & Atractomorpha lata (Motschulsky) & オンブバッ夕 \\
\hline Pieridae & & Acrididae & \\
\hline Colias erate poliographa Motschulsky & モンキチョウ & Patanga japonica (Bolivar) & ツチイナゴ \\
\hline Geometridae & & Gryllidae & \\
\hline Ascotis selenaria (Denis \& Schiffermüller) & ヨモギエダシャク & Oecanthus euryelytra Ichikawa & ヒロバネカンタン \\
\hline \multirow[t]{2}{*}{ Scopula personata (Prout) } & ナミスジチビヒメシャク & & \\
\hline & & Acrididae & \\
\hline Noctuidae & & Stethophyma magister (Rehn) & ツマグロイナゴ \\
\hline Paragabara flavomacula (Oberthür) & キボシアツバ & & （ツマグロバッタ） \\
\hline Paragabara ochreipennis Sugi & チャバネキボシアツバ & & \\
\hline Herminia arenosa Butler & ウスキミスジアッバ & & \\
\hline Hipoepa fractalis (Guenée) & オオシラナミアツバ & & \\
\hline Hypena subcyanea Butler & 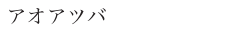 & & \\
\hline Mocis annetta (Butler) & ウンモンクチバ & & \\
\hline Mocis undata (Fabricius) & オオウンモンクチバ & & \\
\hline Trigonodes hyppasia hyppasia (Cramer) & サンカククチバ & & \\
\hline Ctenoplusia albostriata (Bremer \& Grey) & エゾギクキンウワバ & & \\
\hline Chrysodeixis eriosoma (Doubleday) & イチジクキンウワバ & & \\
\hline Microxyla confusa (Wileman) & スジモンコヤガ & & \\
\hline Viminia rumicis (Linnaeus) & ナシケンモン & & \\
\hline Helicoverpa armigera (Hübner) & オオタバコガ & & \\
\hline Spodoptera litura (Fabricius) & ハスモンヨトウ & & \\
\hline
\end{tabular}

メイガ Pleuroptya punctimarginalis (Hampson), チヤノコカクモンハマキAdoxophyes honmai Yasuda, オオウンモンクチバ Mocis undata (Fabricius)， ハスモンヨトウ Spodoptera litura (Fabricius), オオタバコガ Helicoverpa armigera (Hübner) もほぼ全ての調查地で発生が認められたが, 確認個体数は少なかった。調査地によって確認個体数 が異なる種も認められたが, 年次変動も大きく, はっ きりとした傾向は認められなかった。他の15種は，1 〜 2 力所で発生が確認されたのみであり, 確認個体数 も年間で 1 数個体と少なかった。
コウチュウ目では, フタスジヒメハムシ Medythia nigrobilineata (Motschulsky), マメコガネ Popillia japonica Newmann, サルハムシ類の確認個体数が多 い傾向が認められた（Table 4)。泗水町と嘉島町を比 較すると, 嘉島町でこれらの確認個体数が多い傾向が 認められたのに対し，泗水町ではマメコガネの発生が ほとんど認められず，サルハムシ類も2015年にわずか な個体が確認されただけであった。一方，コガネムシ 類の確認個体数は嘉島町より泗水町で多かった。マメ ハンミョウEpicauta gorhami Marseul は, 確認個体 数の年次変動が大きく, 2013年のみ発生が認められた。 
Table 3. Species and their number of individuals of lepidopteran insects feeding on wild soybean, $G$. soja, in Kumamoto

\begin{tabular}{|c|c|c|c|c|c|c|c|c|c|c|c|c|c|c|}
\hline Location & Year & $\begin{array}{l}\text { Paragabara } \\
\text { ochreipennis }\end{array}$ & $\begin{array}{c}\text { Omiodes } \\
\text { miserus }\end{array}$ & $\begin{array}{c}\text { Matsumuraeses } \\
\text { falcana }\end{array}$ & $\begin{array}{c}\text { Omiodes } \\
\text { indicatus }\end{array}$ & $\begin{array}{c}\text { Pleuroptya } \\
\text { ruralis }\end{array}$ & $\begin{array}{c}\text { Pleuroptya } \\
\text { punctimarginalis }\end{array}$ & $\begin{array}{c}\text { Adoxophyes } \\
\text { honmai }\end{array}$ & $\begin{array}{c}\text { Mocis } \\
\text { undata }\end{array}$ & $\begin{array}{c}\text { Spodoptera } \\
\text { Iitura }\end{array}$ & $\begin{array}{c}\text { Helicoverpa } \\
\text { armigera }\end{array}$ & $\begin{array}{c}\text { Chrysodeixis } \\
\text { eriosoma }\end{array}$ & $\begin{array}{c}\text { Ascotis } \\
\text { selenaria } \\
\text { cretacea }\end{array}$ & $\begin{array}{l}\text { Viminia } \\
\text { rumicis }\end{array}$ \\
\hline \multirow[t]{5}{*}{ Shisui } & 2011 & 3 & 1 & 0 & 11 & 1 & 0 & 0 & 0 & 2 & 0 & 0 & 0 & 0 \\
\hline & 2012 & 14 & 1 & 7 & 0 & 0 & 0 & 0 & 0 & 2 & 0 & 0 & 0 & 0 \\
\hline & 2013 & 20 & 3 & 0 & 3 & 0 & 0 & 0 & 3 & 0 & 0 & 0 & 0 & 0 \\
\hline & 2014 & 20 & 2 & 39 & 10 & 0 & 1 & 1 & 0 & 2 & 1 & 1 & 0 & 0 \\
\hline & 2015 & 4 & 23 & 64 & 1 & 42 & 0 & 0 & 0 & 0 & 2 & 0 & 1 & 1 \\
\hline \multirow[t]{3}{*}{ Kashima } & 2013 & 3 & 0 & 3 & 25 & 0 & 0 & 0 & 7 & 2 & 4 & 0 & 0 & 0 \\
\hline & 2014 & 10 & 9 & 5 & 0 & 0 & 0 & 0 & 1 & 1 & 3 & 1 & 0 & 0 \\
\hline & 2015 & 8 & 8 & 1 & 0 & 1 & 1 & 1 & 6 & 0 & 0 & 0 & 0 & 0 \\
\hline \multirow[t]{2}{*}{ Koshi } & 2011 & 2 & 4 & 0 & 7 & 15 & 1 & 6 & 1 & 7 & 3 & 0 & 0 & 0 \\
\hline & 2012 & 26 & 34 & 20 & 0 & 0 & 0 & 0 & 2 & 15 & 5 & 0 & 0 & 0 \\
\hline Ezu & 2011 & 0 & 4 & 1 & 20 & 0 & 2 & 4 & 3 & 7 & 2 & 0 & 0 & 0 \\
\hline Location & Year & $\begin{array}{c}\text { Herminia } \\
\text { arenosa }\end{array}$ & $\begin{array}{c}\text { Salma } \\
\text { elegans }\end{array}$ & $\begin{array}{c}\text { Hypena } \\
\text { subcyanea }\end{array}$ & $\begin{array}{l}\text { Homona } \\
\text { magnanima }\end{array}$ & $\begin{array}{l}\text { Hipoepa } \\
\text { fractalis }\end{array}$ & $\begin{array}{c}\text { Trigonodes } \\
\text { hyppasia } \\
\text { hyppasia } \\
\end{array}$ & $\begin{array}{c}\text { Dentisociaria } \\
\text { armata } \\
\text { okui } \\
\end{array}$ & $\begin{array}{c}\text { Scopula } \\
\text { personata }\end{array}$ & $\begin{array}{c}\text { Ostrinia } \\
\text { sp. }\end{array}$ & $\begin{array}{c}\text { Microxyla } \\
\text { confusa }\end{array}$ & $\begin{array}{c}\text { Ctenoplusia } \\
\text { albostriata }\end{array}$ & unknown $^{\text {a) }}$ & \\
\hline \multirow[t]{5}{*}{ Shisui } & 2011 & 0 & 0 & 1 & 0 & 0 & 0 & 0 & 0 & 0 & 0 & 0 & 6 & \\
\hline & 2012 & 0 & 0 & 0 & 0 & 0 & 0 & 0 & 0 & 0 & 0 & 0 & 9 & \\
\hline & 2013 & 0 & 0 & 0 & 0 & 0 & 0 & 0 & 0 & 0 & 0 & 0 & 5 & \\
\hline & 2014 & 0 & 1 & 1 & 0 & 0 & 0 & 0 & 0 & 0 & 0 & 0 & 10 & \\
\hline & 2015 & 2 & 0 & 0 & 0 & 0 & 0 & 0 & 0 & 0 & 0 & 0 & 18 & \\
\hline \multirow[t]{3}{*}{ Kashima } & 2013 & 0 & 0 & 0 & 1 & 0 & 1 & 0 & 0 & 0 & 0 & 0 & 16 & \\
\hline & 2014 & 0 & 0 & 0 & 0 & 1 & 0 & 0 & 0 & 0 & 0 & 0 & 2 & \\
\hline & 2015 & 0 & 0 & 0 & 1 & 0 & 0 & 0 & 0 & 0 & 0 & 0 & 5 & \\
\hline \multirow[t]{2}{*}{ Koshi } & 2011 & 0 & 0 & 1 & 0 & 0 & 0 & 1 & 1 & 1 & 0 & 0 & 2 & \\
\hline & 2012 & 0 & 0 & 2 & 0 & 0 & 0 & 5 & 0 & 0 & 0 & 0 & 8 & \\
\hline Ezu & 2011 & 0 & 0 & 0 & 0 & 0 & 0 & 0 & 1 & 0 & 2 & 1 & 7 & \\
\hline
\end{tabular}

Table 4. Species and their number of individuals of Coleopteran insects feeding on wild soybean, G. soja, in Kumamoto

\begin{tabular}{cccccccc}
\hline Location & Year & $\begin{array}{c}\text { Medythia } \\
\text { nigrobilineata }\end{array}$ & $\begin{array}{c}\text { Popillia } \\
\text { japonica }\end{array}$ & $\begin{array}{c}\text { Pagria } \\
\text { ussuriensis } \\
\text { P. flavopustulata } \\
\text { Basilepta fulvipes }\end{array}$ & Epicauta gorhami & $\begin{array}{c}\text { Trachys reitteri } \\
\text { T. auricollis }\end{array}$ & $\begin{array}{c}\text { Anola rufocuprea } \\
\text { A. cuprea } \\
\text { Mimela splendens }\end{array}$ \\
\hline Kashima & 2013 & 145 & 93 & 32 & 26 & 17 & 0 \\
& 2014 & 158 & 182 & 441 & 0 & 18 & 1 \\
& 2015 & 49 & 187 & 153 & 0 & 51 & 2 \\
Shisui & 2013 & 47 & 1 & 5 & 31 & 0 & 29 \\
& 2014 & 60 & 0 & 0 & 0 & 2 & 17 \\
& 2015 & 27 & 0 & 19 & 0 & 7 & 16 \\
\hline
\end{tabular}

Table 5. Species and their number of individuals of Orthopteran insects feeding on wild soybean, $G$. soja, in Kumamoto

\begin{tabular}{ccccc}
\hline Location & Year & $\begin{array}{c}\text { Patanga } \\
\text { japonica }\end{array}$ & $\begin{array}{c}\text { Oecanthus } \\
\text { euryelytra }\end{array}$ & $\begin{array}{c}\text { Atractomorpha } \\
\text { lata }\end{array}$ \\
\hline Kashima & 2013 & 73 & 11 & 13 \\
& 2014 & 231 & 52 & 11 \\
& 2015 & 176 & 10 & 14 \\
Shisui & 2013 & 11 & 0 & 7 \\
& 2014 & 46 & 0 & 0 \\
& 2015 & 82 & 0 & 32 \\
\hline
\end{tabular}

バッタ目では, ツチイナゴPatanga japonica (Bolivar) とヒロバネカンタン Oecanthus euryelytra Ichikawa の 確認個体数が，コウチュウ目と同様に泗水町よりも嘉 島町で多い傾向が認められた（Table 5)。オンブバッ 夕 Atractomorpha lata (Motschulsky) は, 両調査地で 確認個体数の明確な違いは認められなかった。

\section{2）主要種の確認個体数の季節的変動}

チョウ目のチャバネキボシアツバ, ヒメクロミスジ ノメイガ, マエウスキノメイガ, ダイズサヤムシガ, ウコンノメイガの確認個体数の季節的な変動を Fig. 1 〜 5に示した。チャバネキボシアツバ (Fig. 1) は，年 次変動が若干認められるものの概ね 6 ないし 7 月から 8 月まで発生が認められた。2013年と2014年の泗水町 では，それぞれ 8 月上〜中旬と 6 月および 7 月末に発 生のピークが認められたが，その他の年・場所では明 確なピークは認められなかった。ヒメクロミスジノメ イガ（Fig. 2）は，2013と2014年は 8〜9月に発生が 認められたのに対し，2015年は，嘉島町で 5 月末〜 7 月, 泗水町で 6 月末〜 8 月に発生が認められた。この うち，2014年の嘉島町と2015年の泗水町では 8 月中〜 
下旬に発生のピークが認められた。マエウスキノメイ ガ（Fig. 3）は2013年の嘉島町で確認個体数が多く, 9 10月にピークが認められたが，2014年と2015年は 発生が認められなかった。一方，泗水町では2013〜 2015年のいずれの年も発生はまばらであった。ダイズ サヤムシガ（Fig. 4）は，泗水町で2014年と2015年の 確認個体数が多く，8月上旬に発生のピークが認めら れたが，2013年は発生が認められなかった。嘉島町で は2013〜2015年のいずれの年も発生はまばらであった。 ウコンノメイガ（Fig. 5）は，2015年のみ発生が確認 され, 泗水町で 8 月末に発生のピークが認められた。
一方，嘉島町では， 8 月上旬に 1 個体が観察されたの みであった。

コウチュウ目のフタスジヒメハムシ, サルハムシ類, マメコガネの確認個体数の季節的な変動を Fig. 6に示 した。フタスジヒメハムシとサルハムシ類は, 年次変 動が若干認められるものの概ね $5 \sim 6$ 月頃から発生が 確認され， $7 \sim 8$ 月に発生のピークが涊められた。マ メコガネは, フタスジヒメハムシとサルハムシ類より もやや発生が遅く, $6 \sim 7$ 月頃から発生が確認され, 8〜9月に発生のピークが認められた。

バッタ目のッチイナゴ，オンブバッタの確認個体数
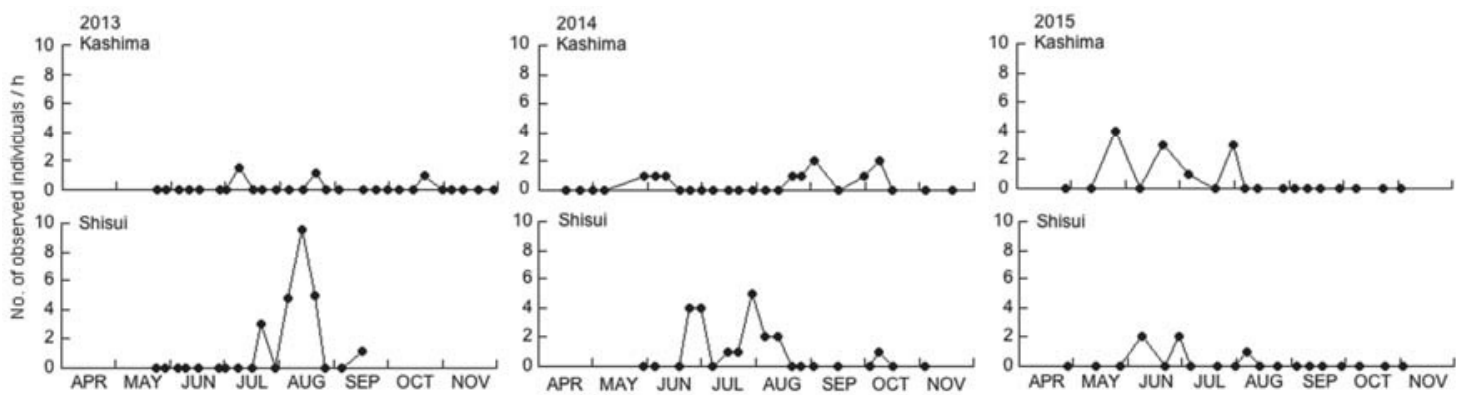

Fig. 1. Seasonal occurrence of Paragabara ochreipennis larvae on wild soybean, G. soja, in Kashima and Shisui, Kumamoto (2013-2015).
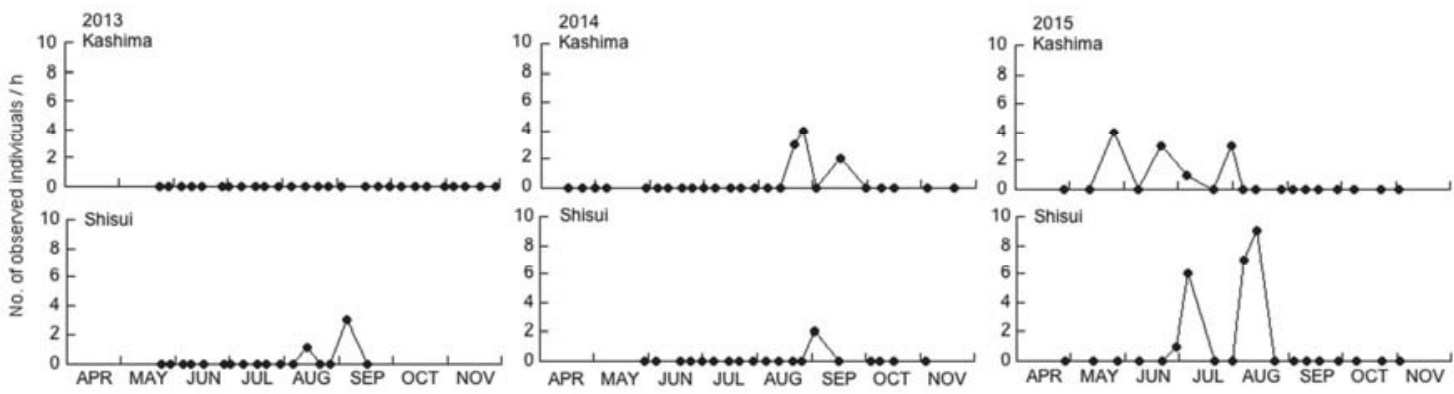

Fig. 2. Seasonal occurrence of Omiodes miserus larvae on wild soybean, G. soja, in Kashima and Shisui, Kumamoto (2013-2015).
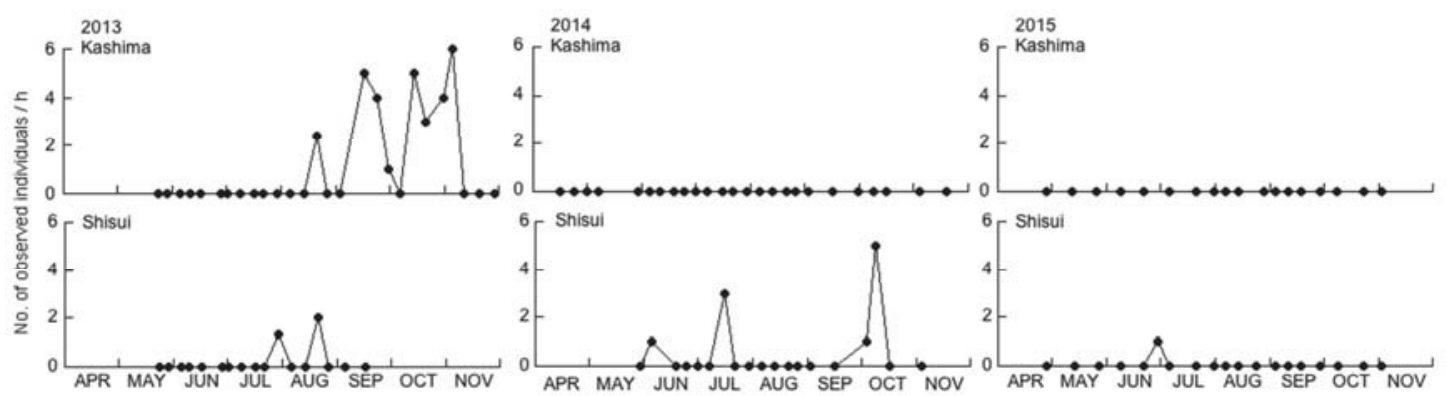

Fig. 3. Seasonal occurrence of Omiodes indicatus larvae on wild soybean, G. soja, in Kashima and Shisui, Kumamoto (2013-2015). 

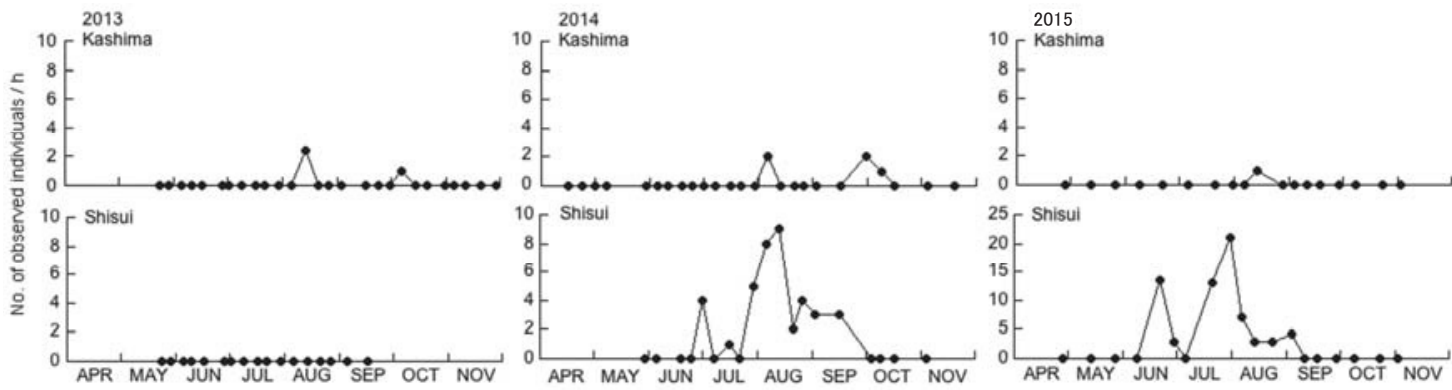

Fig. 4. Seasonal occurrence of Matsumuraeses falcana larvae on wild soybean, G. soja, in Kashima and Shisui, Kumamoto (2013-2015).
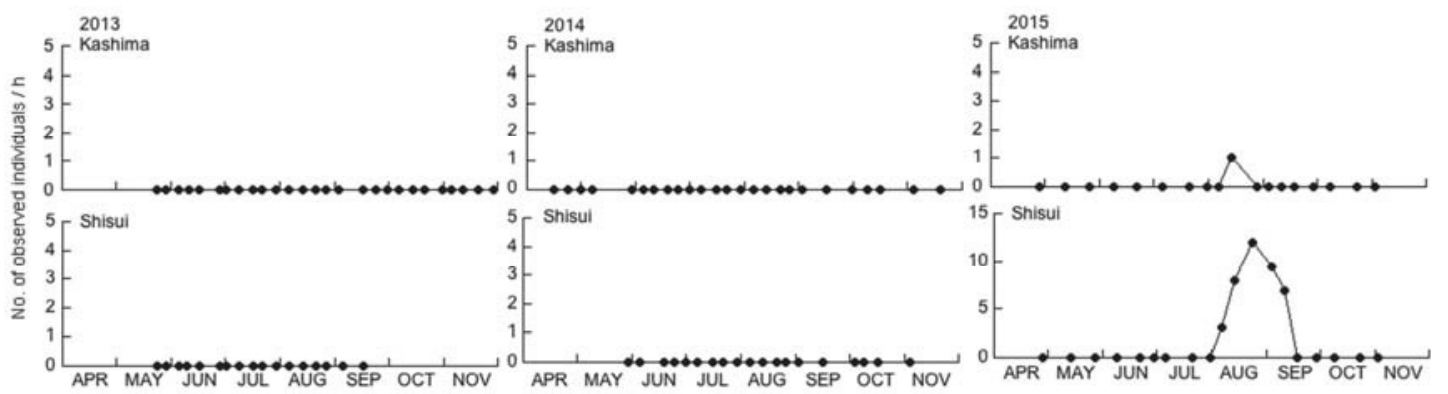

Fig. 5. Seasonal occurrence of Pleuroptya ruralis larvae on wild soybean, G. soja, in Kashima and Shisui, Kumamoto (2013-2015).
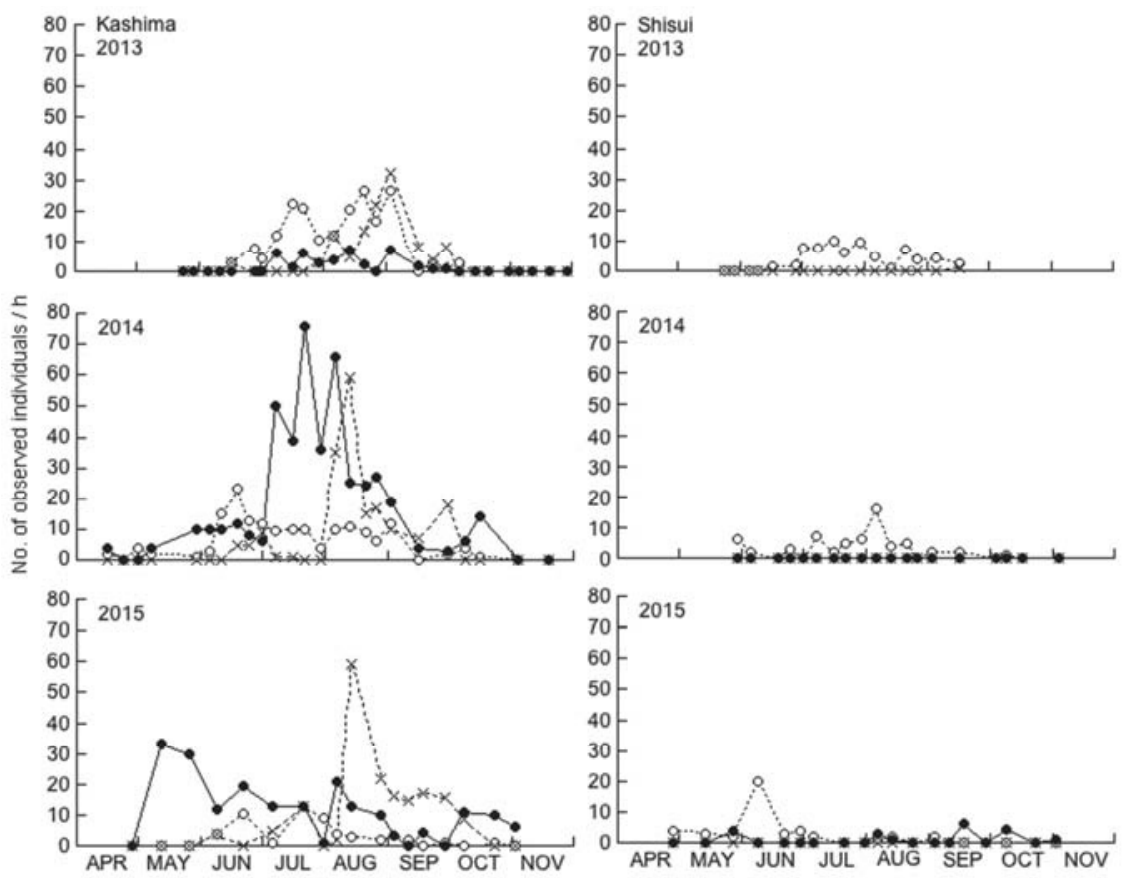

........ Medythia nigrobilineata

- Pagria ussuriensis \& P. flavopustulata \& Basilepta fulvipes

..**- Popillia japonica

Fig. 6. Seasonal occurrence of coleopteran adults on wild soybean, G. soja, in Kashima and Shisui, Kumamoto (2013-2015). 


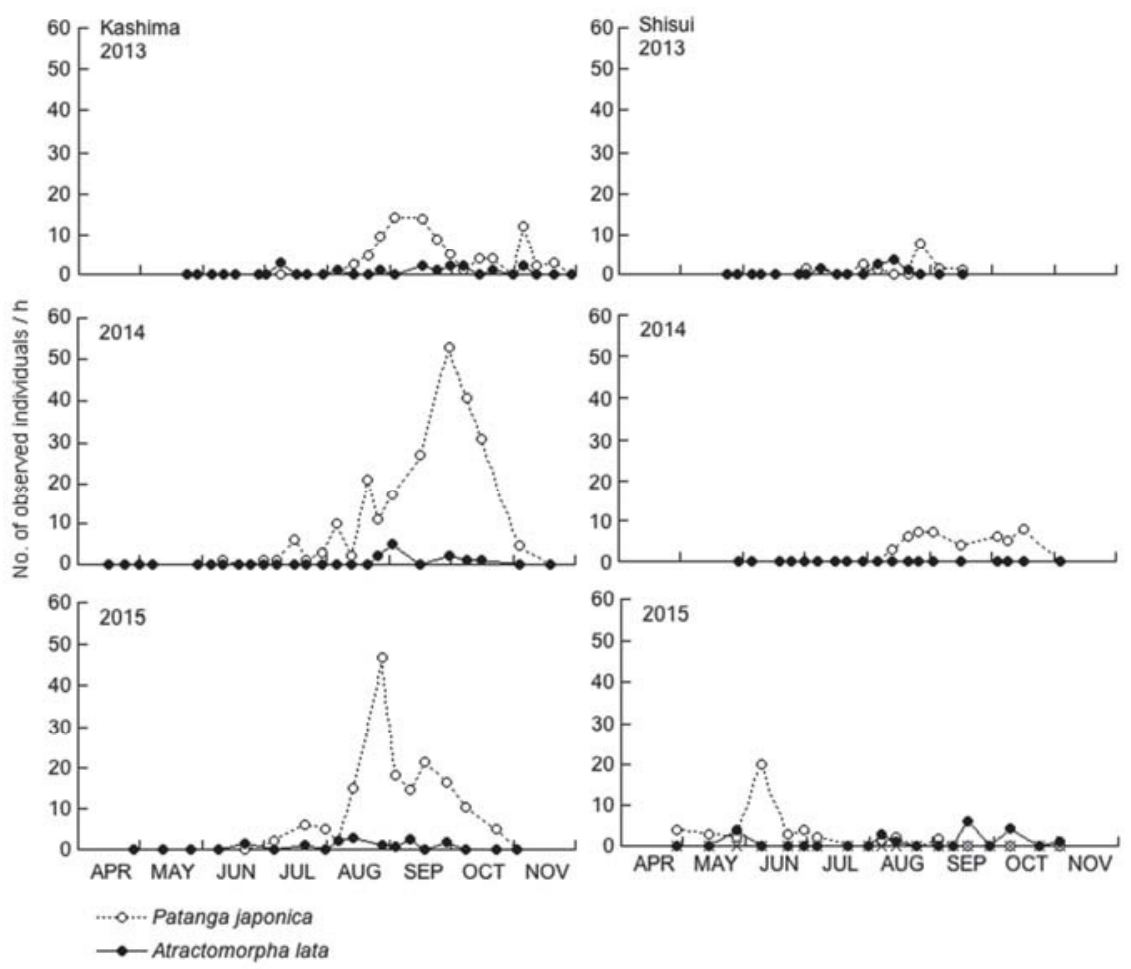

Fig. 7. Seasonal occurrence of orthopteran adults and nymphs on wild soybean, G. soja, in Kashima and Shisui, Kumamoto (2013-2015).

の季節的な変動を Fig. 7に示した。ツチイナゴは, 6 ないし 7 月から10月にかけて発生し，嘉島町では 8〜 9 月に明瞭な発生のピークが認められた。泗水町では 確認個体数が少なく 9 〜 10 月にかけて漸増する傾向が 認められた。オンブバッタは嘉島町では明瞭な発生の ピークは認められなかったが，泗水町では2015年の 8 月に発生のピークが認められた。

\section{考察}

今回，調查対象とした昆虫の多くではツルマメ以外 の寄主植物の存在が知られており, 害虫抵抗性を持つ 遺伝子組換えダイズ（Bt ダイズ）とツルマメとの交 雑が起こった場合でも, その生態的影響は少ないと考 えられる。しかしながら, チャバネキボシアツバ, オ クハマキDentisociaria armata okui Yasuda（安田ら, 2012）など現在までにツルマメのみが寄主植物として 報告されている種については, ツルマメ以外の寄主植 物の存在ならびに遺伝子組換えダイズ（Bt ダイズ） とツルマメの交雑が起こった場合の生態的影響につい て検討する必要がある。このうち, チャバネキボシア
ツバは，本調查および菊地（2013）のいずれでも発生 量が多く, 関東でも中程度の発生が確認されている (安田ら, 2012)。今後, 他の寄主植物の有無と殺虫性 タンパク質（Btトキシン）の殺虫効果について検討 する必要があるが, 寄主植物が限定されッルマメで一 定の発生が認められるチャバネキボシアッバは, Bt 遺伝子のツルマメへの混入による生態的影響を評価す るための指標生物として有望かもしれない。

本調査において，バッタ目のオンブバッタとツチイ ナゴ,コウチュウ目のフタスジヒメハムシは発生が多 く, 菊地（2013）の結果と同様であった。また, チョ ウ目の主要種では, チャバネキボシアッバとウコンノ メイガの発生が多い点が共通していた。一方，本調査 において発生が確認されたバッ夕目のヒロバネカンタ ンやコウチュウ目のマメコガネ, クズノチビタマムシ Trachys auricollis Saunders, ツヤキバネサルハムシ は, 菊地（2013）の調査では発生が確認されていない。 さらに, 上記以外のチョウ目の主要種が, 菊地 (2013) ではウスアトキハマキArchips semistructus (Meyrick) であったのに対し, 本調查ではヒメクロ 
ミスジノメイガ, マエウスキノメイガ, ダイズサヤム シガであった。このような昆虫相の主要種の違いは, 地域間だけでなく本調査における調査場所間でも認め られ, 目レベルでの確認個体数の違いも認められた。 菊地（2013）は, コウチュウ目のマメハンミョウ， シ ロコブゾウムシ Episomus turritus (Gyllenhal), コ ガネムシで発生場所が限定されていることについて触 れ，それぞれ発生の局地性（マメハンミョウ; 小林, 1979), 他の寄主植物の存在（シロコブゾウムシ；日 本応用動物昆虫学会編, 2006), 生息場所の特異性 (コガネムシ；和田・栗原，2012）の観点から考察し ている。ツルマメは日当たりの良い野原, 路傍, 荒れ 地, 河原のほか, 果樹園, 畑地, 水田の畔, 道路法面 など様々な場所に自生し, 様々な植物に絡みついて生 育する（奥田， 1997 ; 吉村ら，2016）。それら生息場 所を含む周辺環境における寄主植物の存在やその資源 量の違いが, 調查地における各種昆虫の発生量の違い をもたらすと考えられた。

ツルマメを摂食する昆虫の発生時期や発生のピーク は，種や調査地によって若干異なる傾向が認められた ものの，概ね $7 \sim 9$ 月の夏期に発生量が多かった。し かしながら，摂食によってッルマメの生育に影響を及 ぼすような種は今回の調査では確認されなかった。し たがって，遺伝子組換えダイズ（Bt ダイズ）と交雑 し害虫抵抗性を持つようになったツルマメが特異的に 残存する可能性は低いと考えられた。

菊地（2013）と同様に，本調査において確認された ツルマメを寄主植物とする昆虫の多くはダイズ害虫と して報告されている（石倉ら，1952；小林・奥， 1976 ; 河野ら, 1985 ; 日本応用動物昆虫学会編, 2006 ; 末永ら，1951など）。しかしながら，例えば， ダイズの重要害虫であるハスモンヨトウは本調査にお いて卵塊や孵化幼虫の集団が確認されたが，ダイズで 観察されるような幼虫の密度増加は観察されず, むし ろ老齢幼虫の個体数は少なかった。調査地では, これ までの同様の調查 (平井, 2007 ; 菊地ら, 1987 ; 河野 ら, 1985 ; 中筋ら, 1973 ; 成瀬, 2000 ; 奥 · 小林, 1970 ; 山中ら, 1972 ; 矢野, 1988など）でも報告され ているクモ類, ゴミムシ類, ハサミムシ類, アマガエ ルなどの捕食性天敵が頻繁に観察された。さらに，種 の同定のために飼育していたチョウ目の多くからは, 寄生蜂や寄生バエが, 特に発生時期の後半に多数羽化 した (データ未掲載)。ツルマメの自生地ではダイズ 畑のように殺虫剂が散布されることはなく, これらの 天敵の活動が活発であることが予想される。したがっ
て, ツルマメ群落でダイズ害虫が多発する可能性は低 く, ダイズ畑に飛来・侵入する害虫類の発生源となる 可能性は低いと考えられる。むしろ天敵類の活動が活 発なことから, ツルマメ群落はダイズ害虫の天敵類の 生息 (繁殖) 場所としての働きを持つことが期待され る。

\section{引用文 献}

平井利明 (2007) ダイズ畑におけるニホンアマガエル の飭構成：広食性捕食者は害虫防除に役立つか？。

応動昆 51 : 103-106

Hymowitz, T. (1970) On the domestication of the soybean. Econ. Botany 24 : 408-421.

石倉秀次 · 永岡 昇 - 小林 尚 - 藤田 優 (1952) 大 豆害虫に関する研究 第 1 報 四国地方に於ける大 豆害虫相. 中国四国農試研報 1 (1)：134-150.

Karasawa, K. (1936) Crossing experiments with Glycine soja and G. ussuriensis. Jap. J. Botany $8: 113-118$.

菊地淳志（2013）中国・四国地方におけるダイズ原種 ツルマメを寄主植物とする昆虫相. 関西病虫研報 $55: 129-133$.

菊地淳志・福与徳文・内藤 篤 (1987) イチモンジカ メムシの捕食性天敵の役割. 関東東山病害虫研報 $34: 147-150$.

小林 尚 (1979) ダイズ害虫の現状と問題点. 植物防 疫 $33: 98-103$.

小林 尚・奥 俊夫（1976）東北地方におけるダイズ 害虫の発生相, 虫害相ならびに虫害発生量の予察に 関する研究. 東北農試研報 $52: 49-106$.

河野 哲・山下優勝・藤本 清 (1985) ダイズ害虫の 生態と防除に関する研究 第 1 報 兵庫県のダイズ 圃場における小動物相. 兵庫農総七研報 $33: 27-36$. 中筋房夫 ·山中久明 - 桐谷圭治 (1973) 捕食性天敵と クロルフェナミジン剤の超低濃度散布によるハスモ ンョトウの防除. 応動昆 $17: 171-180$.

成瀬博行 (2000) ダイズ害虫ウコンノメイガ,

Pleuroptya ruralis (Scopoli) の生態と防除に関す る研究 IV.夏世代個体群の動態. 富山県農技七研 報 $19: 31-40$.

日本応用動物昆虫学会編（2006）農林有害動物 ·昆虫 名鑑増補改訂版. 日本応用動物昆虫学会 (東京), pp.387.

Oka, H. (1983) Genetic control of regenerating success in semi-natural conditions observed 
among lines derived from a cultivated $\mathrm{x}$ wild soybean hybrid. J. Appl. Ecol. 20 : 937-949.

奥田重俊（1997）ッルマメ。日本野生植物館（奥田重 俊編著)。小学館 (東京), pp. 88

奥 俊夫・小林 尚 (1970) 東北地方の夏作物畑にお ける節足動物群集に関する研究. 東北農試研報 $40: 107-184$.

末永 一・松尾寛一・酒井久夫 ·山元四郎 (1951) 九 州地方における大豆害虫の種類。九州農業試験場彙 報 1（1）:78-79.

和田 薰・栗原 隆 (2012) スジコガネ亜科. 日本産 コガネムシ上科標準図鑑（岡島秀治・荒谷邦雄監 修)。学研教育出版 (東京) : pp.326-360.
山中久明・中筋房夫・桐谷圭治（1972）八スモンヨト ウの生命表と生物的死亡要因の評価. 応動昆 16 : 205-214.

矢野栄二（1988）筑波におけるハスモンヨトウの天敵. 関東東山病害虫研報 $35: 145-146$.

安田耕司・榊原充隆・菊地淳志・水谷信夫 - 松村正 哉・加賀秋人 - 菊池彰夫 ・ 高田吉丈 - 大小信彦 （2012）ッルマメを寄主植物とするチョウ目昆虫. 蛾類通信 $263: 333-335$.

吉村泰幸 · 加賀秋人 - 松尾和人（2016）遺伝子組換元 ダイズの生物多様性影響評価に必要なツルマメの生 物情報集. 農環研報 $36: 47-69$.

(2018年 3 月 30日受領， 8 月13日受理） 